\title{
Tyd leer jou lieg
}

Dis die doodsakker van die nag. Die tyd in die daaglikse liggaamsiklus wanneer die mens gevaar loop om deur daardie onbekende membraan te glip, die ewigheid in, omdat die organe nie al die afvalstowwe kan verwerk nie. Die lewensklok gaan staan dan stil. Dis ook gewoonlik die tyd dat ek wakkerskrik en beangs deur 'n lys in my kop worstel: watter werk ek nog moet doen, watter ek dalk nie gedoen het nie. Dan lê ek en wroeg oor vergange jare; oor die onvermydelike realiteit dat my eie klok ook sal stol; oor die hoeveelheid mense en diere wat ly terwyl ek teen die donker in na die plafon staar; en oor die aarde wat kreun en kraak onder al die asems en gretighede. Één voordeel, tog: ek het gelukkig niks uit eie liggaam oor wie se toekoms ek my hoef te bekommer nie.

Dit is een van my terugkerende drome wat my wakker gemaak het. Ek het weereens kaal en paniekbevange deur vreemde strate geloop en kaal êrens op 'n onbekende markplein gaan staan: omring deur vriende, vyande, familie - gesigte uit die lewe én die dood. Al wat ek in die droom het om my skaamte mee te bedek, is iets soos 'n wit waslap of uitgewaste manssakdoek. (Gebruik mans nog lapsakdoeke?) Ek vermoed ek weet wat die psigoanaliste hieroor sal kwytraak. Die droom, soos ander (byvoorbeeld waarin al my tande losraak en ek hulle een vir een met my eie vingers uittrek, óf die een waarin ek vasgekeer is in 'n plek vol wriemelende slange), is waarskynlik 'n aanduiding dat ek iets onderdruk, of dat ek gestres is. Stres is tog so 'n misbruikte konsep. Is daar nie in elk geval stres vanaf die oomblik dat die gamete teen mekaar aanplof nie? Nietemin, om kaalbas voor almal in my droom te paradeer is deesdae 'n veel erger nagmerrie (en dagmerrie), want ek is nou in my middeljare en vel en lyf wil teen wil en dank hul eie rigting inslaan (oefening nieteenstaande). Die naakparadering is iets so vernederend en skandalig soos om te droom dat ek 'n verhouding met een van die studente het - 'n erotiese taboe vir vrouens van my jare en tog iets wat sosiaal aanvaarbaar skyn te wees vir die manlike geslag: soos 'n menigte boekstawings uit die letterkunde, geskiedskrywing en die media getuig.
Ek klim uit die bed en voel-voel my pad in die donker, verby die vier honde wat soos bedmatjies en deurstoppers orals rondlê, na die badkamer waar ek 'n sigaret agter toe deure rook en nog 'n paragraaf uit Allan Carr's Easy way to stop smoking lees. Die boek lê al agtien maande in die rak langs die toilet en ek het dit al drie keer deurgelees. Ek rook agter geslote grendels en by oop vensters sodat my puriteinse metgesel ('n oud roker), wat my nagliks uit die bed poep en snork, nie moet wakker word nie. Die knaende gekerm oor my stink verslawing kan ek beswaarlik in die daglig uitstaan. Soos gewoonlik slaap hy so vas dat 'n rower sy snorkkleppe uit sy strot kan steel sonder om hom te laat roer (of sy kake oop te klamp). Die slaap van iemand sonder slegte gewete of sonder gedagte.

Terug in die bed, kyk ek op die selfoon om seker te maak dat ek nog 'n paar ure oor het om te lê en kommer. Daar is 'n teksboodskap. Ek het nie gehoor toe dit deurgekom het nie.

"Ek luister na Patsy Cline", staan daar, "en ek wonder wat ons gedoen het om so 'n wonderlike verhouding te verwoes". Received: 02:06:02.

My wentelbaan kantel. Met een veeg is ek terug in 1985, waar ek en my toekomstige man uit die rolprentteater by Sterland stap - erg verlief. Ons albei loop skaamteloos en snot afvee oor Jessica Lange se roerende vertolking van Cline se tragiese lewe in Sweet Dreams. Ons is saam boos oor hoe haar rokjagter van 'n nikswerdman haar behandel het. Ek en hy hou nie eers van countrymusiek nie.

Nou is ons reeds sewentien jaar geskei. Toe ek hom jare gelede weer ' $n$ keer gesien het, het hy my so geïrriteer met sy rympie dat hy en sy nuwe vrou se mantra nou sus en so is, dat ek gewens het ek kon 'n bleddie acid cap in sy gat opdruk sodat hy in sy eie mandala van mantras in sy moer kon wegvlieg. Tog, mettertyd vat mens maar die lewe se herinneringe en teleurstellings. $\mathrm{Na}$ 'n ruk sluit jy dit dig in die grysstof weg, en fokus op die doelwitte van die hede.

Soos die swart chroom van die nag (soos Jim Morrison dit stel) omrol en ek die niet bly instaar, voel ek stelselmatig

\begin{tabular}{|c|c|c|}
\hline 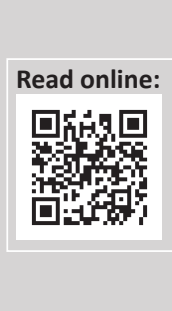 & $\begin{array}{l}\text { Scan this QR } \\
\text { code with your } \\
\text { smart phone or } \\
\text { mobile device } \\
\text { to read online. }\end{array}$ & $\begin{array}{l}\text { Author: Mathilda Slabbert }{ }^{1} \\
\text { Affiliation: }{ }^{1} \text { Department of English, Stellenbosch University, South Africa } \\
\text { Correspondence to: Mathilda Slabbert } \\
\text { Email: mslabbert@sun.ac.za } \\
\text { Postal address: Private Bag x1, Matieland 7602, South Africa } \\
\text { How to cite this article: Slabbert, M., 2015, Tyd leer jou lieg, Literator 36(1), Art. \#1108, } 2 \text { pages. http://dx.doi. } \\
\text { org/10.4102/lit.v36i1.1108 } \\
\text { Copyright: (C) } 2015 . \text { The Authors. Licensee: AOSIS OpenJournals. This work is licensed under the Creative Commons } \\
\text { Attribution License. }\end{array}$ \\
\hline
\end{tabular}


hoe iets vlak agter my sternum begin losskeur. My borskas van vlees, been en senuwee voel soos 'n weerbarstige korset wat uiteindelik oopgespalk lê onder die hande van my eie inkwisisie. Die grootste hartseer dan tog: my eie tong kry dit nie gesê nie. Om die klammigheid uit die leivore om my oё te hou en nie my bedmaat wakker te maak nie, probeer ek dink aan die wyshede van skrywers en filosowe wat die liefde se verdriet talig kon raakknyp. Die beeldspraak van daardie ou Dertigermeester kom vanselfsprekend by my op. Alhoewel in 'n ander konteks, vind ek aanklank by sy woorde: "jy is deur my gevleg gerank; in die grys-wit groewe van die senuwee". Maar, agterna onthou ek dat die woorde ook 'n gedeelde moment oproep en ek skuif dit summier opsy om plek te maak vir 'n ander digter se woordspel. Iets nader aan my huidige belangstellings, neergepen deur 'n vrou, gebore in die kontrei waar ek nou woon:

Die aandag van jou oë, toe dit my verlaat,

Het my die groen en bruin gevlekte skoonheid

Van die aarde nagelaat.

Maar, my droefheid bly skeur aan die some en ek worstel oor landsgrense na die werk van iemand wat ook op gesplete pote van liefde vir die letterkunde en meer as een taal loop. Uit Julian Barnes se spotfiksie oor Flaubert kry ek 'n kolskootsin: "Old love is a rusty tank standing guard over a slabby monument." Die 'slabby monument' pla my. Letterlik sny die suggestie van iets kouds en afsydigs té na aan die waarheid, en ek gryp na 'n ander emosionele messteek uit dieselfde boek: "happiness is a scarlet cloak whose lining is in tatters". Tog, ek bly soek na 'n vrou se woorde wat 'n pleister kan plak. Miskien iets wat my sommer ook sal laat beter voel omdat ek ná die groot skeisaak ook redelik gou hier en daar gaan wei het. Op die oog af, skynbaar nie gepla deur die skeuring nie. Dan eerder die satiriese, snedige woorde van daardie katterige wysneus uit New York? Ja, sy wat toesnou: "better a heart a-bloom with sins than hearts gone yellow and dry".
Die tyd tik. Die nag bly lank. Weemoed pluk-pluk díe kant en daai kant aan my. Ek dink en dink. Hou dit dan nooit op nie? Wat van die gesegde dat tyd alles laat vervaag, en pyn oor verlies laat verflou?

Ek onthou sy duim met die geboortevlek. Sy skewe glimlag ...

Uiteindelik draai ek op my sy, gesig na die kas, en besluit om maar soos altyd agter die smal, poëtiese ruggie van Emily Dickenson berusting te probeer vind. Om soos haar getroue "single hound" aan die leestekens en minimalisme van haar gedigte te hang totdat die ellendige hartseer padgee:

That Love is all there is,

Is all we know of Love;

It is enough, the freight should be

Proportioned to the groove.

Teen dagbreek staan ek op. Volg die roetine: Maak koffie, drink my hormoonaanvulling; bad. Moenie dat die ander een sien jy is ontsteld nie. In díe huis is daar plek vir net één eks. Ek wonder watter teorieë ek vandag met my studente gaan bespreek. Miskien moet ek terugkeer na die komplekse netwerk oor hoe skrywers van outobiografieë feite vermeng met fiksie in hul pogings om die waarheid (as daar so iets is) weer te gee, asook 'n heroorweging van die rol van die geheue in hierdie proses. Of dalk 'n ondersoek na die metodes wat gebruik word om die slaggate van nostalgie aan te pak: 'n skynbaar kakkerige tegniek in lewensbeskrywing, wat tog so maklik tot sentimentele en sensasionele uitbeeldings aanleiding kan gee.

\section{Literatuurverwysings}

Barnes, J., 1985, Flaubert's parrot, Picador, London.

Dickinson, E., [1968] 2004, 'The single hound', Emily Dickinson: Poems selected by Ted Hughes, Faber and Faber, London.

Muller, P., 2002, Die aandag van jou oë. Die aandag van jou oë, Tafelberg, Kaapstad.

Parker, D., 1989, 'The whistling girl', in The collected Dorothy Parker, Penguin, London.

Van Wyk Louw, N.P., 1978, “'Ballade van die Bose" en "Ballade van die Nagtelike Ure"', Groot verseboek, Opperman, D.J. (red.), Tafelberg, Kaapstad. 